\title{
Extending Technology Acceptance Model to EPV Application
}

\author{
Shuhaida Mohamed Shuhidan ${ }^{1}$, Nurul Syahida Ayza Abd Samad ${ }^{1}$, Zuraidah Mohd Sanusi $^{1}$ \& 3 , Saidatul Rahah Hamidi ${ }^{2}$, \\ Razana Juhaida Johari ${ }^{3} \&$ Farah Aida Ahmad Nadzri ${ }^{1}$ \\ ${ }^{1}$ Accounting Research Institute, University Technology MARA, Malaysia \\ ${ }^{2}$ Fac of Computer and Mathematical Sciences, Universiti Technology MARA, Malaysia \\ ${ }^{3}$ Fac of Accountancy, Universiti Technology MARA, Malaysia \\ Correspondence: Shuhaida Mohamed Shuhidan, Accounting Research Institute, University Technology MARA, \\ Malaysia.
}

Received: April 30, 2019

Accepted: May 30, 2019

Online Published: June 11, 2019

doi:10.5430/ijfr.v10n5p398

URL: https://doi.org/10.5430/ijfr.v10n5p398

\begin{abstract}
This study intends to determine the acceptance of the technology in making ethical performance among auditors. We have reviewed current technology acceptance theories and formulates a unified model for the context of EPV application based on several constructs which is: performance expectancy, effort expectancy, social influence, facilitating conditions, hedonic motivation, motivating and impeding factor and perceive risk. Hypothesis are generated and their validity is analyzed by using Pearson Correlation and Multiple Linear Regression and a model has been produces for findings of the study namely Technology Acceptance towards EPV application (TAEPV). From the model, hedonic motivation has been excluded because it shows no significant relationship towards technology acceptance which means it is not suitable to be a factor to determine technology acceptance of EPV application. The respondents are tertiary students that are undergoing study in accounting, as they are the future pool of talent for the workforce. The results show that TAEPV outperforms current technology acceptance model by significantly improving the R-squares. Thus, this study makes modest theoretical and empirical contributions to the professional sector to (1) analyse existing tools in measuring ethical performance of individuals, (2) propose a unified model of technology acceptance toward EPV application and (3) evaluate technology acceptance in implementing EPV application. As for recommendation, it is hoped that TAEPV theories can be then evaluated by the financial auditors to assess their acceptance and use behavior of EPV application, the pioneer of professional judgment system.
\end{abstract}

Keywords: professional judgment system, technology acceptance

\section{Introduction}

Malaysia is one of many countries that are influenced with negative perception regarding corruption and fraud incidents (Amanuddin et al, 2015). Nowadays, public perception on government effectiveness in fighting corruption is still low instead of various initiative from the government to increase people confidence towards the credibility of professionals in their profession due to the monetary issues (EUROSAI Task Force on Audit \& Ethics, 2014). Auditing play big responsibility in the administration and operation of an organization as their credibility, reliability and ethical performance are essential with regards to client or the general population who demand services from them. There are many jobs based on discipline in the world and auditing are the profession that relates to the issues of individuals in the public, property and resources of individuals. The auditor's obligation is to verify monetary articulations of the organization by deciding whether the financial statement have given a genuine and reasonable perspective of the organization's execution and budgetary position for the reviewed year (Hussin \& Iskandar, 2015). Moreover, auditor is relied upon to have adequate knowledge to assess the danger of extortion in the organization, and are required to report to the board any misrepresentation dangers found amid their examinations. Anyhow, the auditors frequently wind up in a strange position since they must answer to senior administration inside the organization not straightforwardly to board of director, yet are relied upon to impartially survey administration's lead and adequacy.

The reducing level of trustworthiness among people, organization and the public by progression of debasement, inadequacy, acts of neglect, misrepresentation and other unscrupulous conduct have prompt to a few ambiguities 
about genuineness and trust of professional auditor. Ethical behavior is one of the basic individual aptitude that professional auditor must have yet it has been demonstrated by the research reports that professional auditor is having after every one of the guidelines identifying with their calling aside from good obligation a commitments or ethics. Behaving ethically not only influenced profession of an auditor but also the whole organization. Therefore, auditor professional ethics is essential for auditor and those included in reviewing and bookkeeping to secure people confidence regarding services that auditors provided (Bakhtiari \& Azimifar, 2013; Lin, 2018).

Information technology offers the tools for organizations to react successfully and effectively to the changes to remain competitive. Furthermore, rapid changes of information technology have influence auditing sector as they need an alternate strategy and technique for auditing in a technology driven environment. Auditing organization that incorporate information technology into the audit procedure has been proved to be more advanced in identifying risk as compared to conventional methods (Mustapha \& Lai, 2017; Liu \& Kao 2018). Previously, Malaysian Institute of Accountants (MIA) has adopted professional measure from United States which is the international standards on auditing in developing measurement standards for auditing practices in Malaysia. Subsequently, auditors in Malaysia are guided by an indistinguishable auditing structure from different nations despite the context that the setting inside which the audit happens may vary (Mohd Iskandar, Nelly Sari, Mohd-Sanusi \& Anugerah, 2012)

This research intends to examine the importance of personality and value for individual, specifically auditor using an application called ethical personality value (EPV), which has been developed by a group of researchers in Accounting Research Institute (ARI) recently. This application is a catalyst for professional judgement system to measure an individual performance and the knowledge, which has been extracted from a list of social sciences research (Mohd-Sanusi \& Mohd-Iskandar, 2006; Liu \& Wang 2018). We intend to study technology acceptance with the introduction of EPV and potential risk that may arise with the implementation of new technology. To accomplish this task, it was necessary to develop a valid instrument for obtaining user evaluations of the EPV application. A pilot study was initiated to introduce the application with potential end-users and to measure questionnaire's reliability using cronbach alpha test. The study demonstrated that the perceptions of end-users can be measured and evaluation of the system from a conceptual viewpoint can be documented to enhance system applicability while making judgement.

\subsection{Ethical Performance Measure}

Firstly, auditing has a big responsibility in the administration and operation in an organization. Business risk procedure and system incapability can be easily identified by the organization that perform proper financial auditing as the respective restorative move will be operate when it is needed. Thus, to keep up an auditor's credibility, their performance of the behavior must be observed. Building up performance measures is basic in figuring out whether a review action is meeting its objectives and goals, steady with the most astounding quality practices and guidelines.

As indicated by Morris (2009) the auditing organization require measurement standard that can be used to survey how well the association accomplishes its objectives, lastly, must have some method for rectifying or reconstruction methodologies if objectives are not being met. Auditor need to act in a good and moral way as they take part in the review process as the good and moral measures would advance an objective of value reviews and makes this the reason for the company's authoritative culture (Morris, 2009). However, based on initial review, there is none specific professional measurement that is design specially for the financial auditor of the organization to measure auditor's ethical performance in our country.

This concern the implementation of well establish tools to measure ethical performance of an auditor in respond to government initiatives towards an employee's competence that could fight corruption along their career as highlighted in second National Key Result Areas (NKRA).

As EPV is newly develop technology, the technology acceptance needs to be studied and potential risk that may arise with the implementation of this new technology needs to be evaluated. Sun and Wang (2013) suggested that technology acceptance theories need to be compared and integrated to explain health technology acceptance behaviour. The technology is for health sector and a mobile application called mobile health services (MHS) have been developed for the user (Berger, Klapper, Martinez-Peria \& Zaidi, 2008). Hence, there's a need to review technology acceptance theories and propose a unified model to integrate current model from user context in studying technology acceptance of epv application.

The objective of this research is to analyse existing tools in measuring ethical performance of individuals and propose a unified model of technology acceptance toward EPV application. The model itself will be then be evaluated in the form of technology acceptance in implementing ethical personality value (EPV) application. 


\section{Literature Review}

\subsection{Auditing Profession}

Generally, accountant work in public or private practice, and rely upon to stick to moral benchmarks that are intended to guarantee that they demonstration in a steady and good way. Code of conduct need to be taken into consideration to be a certified auditor. An auditor must consent to maintain the ethical standard and know the consequences they might be expelled from the association if they neglect to do as such. This is because ethical standards and principles used as estimation of awful or great conduct (Mohamed Alteer, Bin Yahya \& Harashid Haron, 2013; Liu, et.al2018)

Auditing are basic segments of any monetary endeavor as they assume an imperative part in adding to the adequacy and productive working of business operations, the capital markets, and the economy by adding believability to financial statement. Audit expresses a conclusion on the monetary explanations whether it exhibits a genuine and reasonable perspective of the venture. Subsequently, auditors possess a prime place in expectation gap the desire hole amongst administration and the clients of the distributed money related reports (Shamsuddin, Manijegar, Kirupanangtan, Rahman \& Selvanathan, 2014).

\subsection{Ethical Decision Making}

When someone make decision while dealing with contention requiring moral judgments in view of issues of ethical quality, it is an ethical decision (Kung \& Huang, 2013). Moreover, it is including the procedure of identification, thought, crave, into a conduct that is moral or untrustworthy about certain moral issues. From the earliest starting point of the procedure, the auditors regularly neglected to recognize an issue that is in contact with the are moral. The auditor's professional conduct has assumed an essential part in expanding the certainty of the user financial statement, to affirm the uprightness of the financial statement.

\subsection{Creative Accounting}

Creative accounting is the auditing process comprises of supervise many matters of judgment and of settling clashes between contending ways to deal with the presentation of the aftereffects of money related occasions and exchanges. It additionally alluded to pay smoothing, income administration, gaining smoothing, money related designing and corrective bookkeeping as stated by the USA and Europe.

Improper auditing practice and outrage can demolish any establishment, there is the need to reestablish trustworthiness and open certainty to auditing operations, the auditor ought to be reinforced to react rapidly to the horrifying misuse and negligence in the realm of business and force endorses on wrongdoers. Besides, there is critical requirement for work on observing to start keeping in mind the end goal to raise the nature of money related report universally (Detragiache, Tressel \& Gupta, 2006). Hence, by migrating the professional measurement to the Internet of Things (IoT), there are many benefit that can be achieve which also may enhance the monitoring process of an auditor's credibility.

\subsection{Tools to Measure Ethics}

Generally, organizations demand an employee with high ethical behavior, professional values and attitudes in most of today's profession. Psychometric test is the best approach to help each of these issues. Psychometric tests will help in getting to human conduct that will furthermore help in assessing the likelihood of an individual suit the occupation prerequisite (Fernandés, 2014; Loukil, 2017). Psychometric tests are target measures which a few businesses use to help them select the correct contender for occupations. Psychological evaluation instruments are data gathering methods that permit perception and depiction of specific practices and can be delegated self-reports, perception, subjective strategies, projective and target systems. The sorts of self-testing are surveys, scales, inventories, systems of self-enrollment and interview (Mobaraki, 2012).

There are five tools to measure ethics that are being discusses which is Authentic Leadership Questionnaire (ALQ), Corporate Ethical Values Scale (CEV), The Ethics Position Questionnaire (EPQ), Malaysian Integrity Test (MIT), Ethical Personality Value (EPV) and the representation of each constructs of the tools is simplified in Table 1.

Authentic Leadership Questionnaire (ALQ): Authentic Leadership Questionnaires is a questionnaire based measurement for gathering information from the employee that was develop on 2007. ALQ aims on specific aims which is to identify leadership quality that a person has as it is "a theory-driven leadership survey instrument designed to measure the components that have been conceptualized as comprising authentic leadership". 
Table 1. Ethical performance constructs

\begin{tabular}{|c|c|c|c|c|}
\hline Test & Purpose & Variables & Process & Method \\
\hline $\begin{array}{l}\text { EPQ } \\
1980\end{array}$ & $\begin{array}{l}\text { To get data of the } \\
\text { personal ethics } \\
\text { orientation of the user }\end{array}$ & $\begin{array}{l}\text { Level of idealism } \\
\text { Level of relativism } \\
\text { Audit Sector: Yes }\end{array}$ & $\begin{array}{l}\text { Auditor need express } \\
\text { their level of } \\
\text { agreement based on } 5 \\
\text { point Likert scale }\end{array}$ & Pen and paper \\
\hline $\begin{array}{l}\mathrm{CEV} \\
1989\end{array}$ & $\begin{array}{l}\text { To determine about } \\
\text { employee perceptions }\end{array}$ & $\begin{array}{l}\text { Manager's ethics } \\
\text { Manager concern about ethics } \\
\text { Consequence of employee behaviour } \\
\text { Audit Sector: Yes }\end{array}$ & $\begin{array}{l}\text { Employee need to } \\
\text { answer the question } \\
\text { and divided by five to } \\
\text { get CEV score }\end{array}$ & Pen and paper \\
\hline $\begin{array}{l}\text { ALQ } \\
2007\end{array}$ & $\begin{array}{l}\text { To evaluate element that } \\
\text { have been identified } \\
\text { based on authentic } \\
\text { leadership for individuals }\end{array}$ & $\begin{array}{l}\text { Self-awareness } \\
\text { Transparency } \\
\text { Ethical/moral } \\
\text { Balance processing } \\
\text { Audit Sector: Yes }\end{array}$ & $\begin{array}{l}\text { The user need to } \\
\text { answer a set of } \\
\text { question and } \\
\text { calculate manually to } \\
\text { indicater his/her } \\
\text { authentic leadership }\end{array}$ & Pen and paper \\
\hline $\begin{array}{l}\text { MIT } \\
2016\end{array}$ & $\begin{array}{l}\text { To calculate a recruit's } \\
\text { inclination on integrity } \\
\text { via an algorithm }\end{array}$ & $\begin{array}{l}\text { Comprehen-sive integrity assessment } \\
\text { Audit Sector: No }\end{array}$ & $\begin{array}{l}\text { Police new recruits } \\
\text { need to perform in } \\
\text { this assessment }\end{array}$ & Online \\
\hline EPV & $\begin{array}{l}\text { To evaluate ethics, } \\
\text { personality and values } \\
\text { for financial auditors }\end{array}$ & $\begin{array}{l}\text { Ethics } \\
\text { Personality } \\
\text { Value } \\
\text { Audit Sector: Yes }\end{array}$ & $\begin{array}{l}\text { Assess score of } \\
\text { assessment for ethics, } \\
\text { personality and value }\end{array}$ & Online \\
\hline
\end{tabular}

Corporate Ethical Values Scale (CEV): Hunt, Chonko and Wood (1989) has develop a set of questionnaires that purposely test on the employee's personality which is Corporate Ethical Values Scale (CEV). CEV tends to answer three concerns.

The Ethics Position Questionnaire (EPQ): It was developed by Forsyth (1980) to measure ethical orientation of an auditor. It provides a measure or scale of the ethical orientation constructs in two major perspective which is idealism and relativism and widely used in West country and also validated in Malaysian studies (Jermsittiparsert, 2016; Johari, Mohd Sanusi \& Ismail, 2012; Johari, Mohd. Sanusi \& Vincent, 2017).

Malaysian Integrity Test (MIT): MIT is a proactive measure to strengthen the Government Transformation Program (GTP) which incorporates the requirement for the police constrain to push ahead and to instill elite, uprightness and dynamism among its work force. MIT is additionally an innovation upheld respectability appraisal which has been created by the police as a team with the Ministry of Science, Technology and Innovation (MOSTI).

Ethical Personality Value (EPV): Ethical Personality Value (EPV) application is a professional judgment system which available in mobile and desktop version that offers a comprehensive assessment on ones' ethicality; based on personality and values.

\subsection{Technology Acceptance Theories}

Technology acceptance is regarded as one of the most important research areas in the Information Systems (IS) research (Fiserova, Teply \& Tripe, 2015). It engages in understanding the variety of factors that determine users' intentions to adopt a technology and their actual technology usage behaviours (Berger, Klapper, Martinez-Peria \& Zaidi, 2008). There have been several theoretical models that are widely used to evaluate a system or application namely theory reasoned action (TRA) (Fishbein \& Ajzen, 1977), theory of planned behavior (TPB) (Ajzen, 2011), theory acceptance model (TAM) (Davis, 1989) and unified theory of acceptance and use of technology (UTAUT2) (Venkatesh, Thong \& $\mathrm{Xu}, 2012$ ). In order to visualize the risk that might associates new technology acceptance, theory of perceive risk also being discuss in the study (Ahmed, Zin \& Majid, 2016).

Theory Reasoned Action (TRA): It recommends that a man's conduct is specifically identified with their goal to 
change the conduct. An important step towards conduct change is the way a person controls their intention. TRA made from disposition, social impact and behavioral expectation.

Theory of Planned Behaviour (TPB): It recommends that the main consideration in human conduct is expectation which is influenced by demeanor toward conduct, subjective standard and perceive behavioral control. Subjective standard (SN) communicates the apparent social weight on the individual who expects to play out the conduct.

Theory Acceptance Model (TAM): It explain acceptance of new technology by incorporate personal behavior of the user. External factors which influence internal beliefs, attitudes and intentions are being emphasized by the model. perceived usefulness (PU) and perceived ease of use (PEOU) have significant positive effects on attitude towards usage. PU is a client accepts by utilizing specific framework, will build work execution.

Unified Theory of Acceptance and Use of Technology (UTAUT): The unified theory of acceptance and use of technology (UTAUT) evolves from comprehensive review from existing model which focus on behavior of information system and intends to categorize factor influencing behavior of the user to explain about the model more precisely.

Theory of Perceive Risk: Theory of perceived risk has been used to explain the consumer's behavior. There are six elements of perceive risk which is financial, performance, social, physical, privacy, and time-risk (Yaghoubi, 2011).

\subsection{Comparison of Constructs in Technology Acceptance Theories}

There are five prominent theories are being compared, in order o formulate a Unified Theory of Technology Acceptance towards EPV application, in Table 2.

Through the comparisons of the five prominent models, we can see that TAM captures only the components of performance and effort expectancy, TPB and UTAUT captures the first four components but does not consider the component of perceive risk. In contrast, perceive risk does not include the components of effort expectancy and social influence. Therefore, the integrated model is expected to have greater predictive power than any of the alternative models.

Table 2. Comparison of five prominent theories

\begin{tabular}{|c|c|c|c|c|c|c|}
\hline Unified Model & Constructs & TRA & TPB & TAM & UTAUT & UTAUT2 \\
\hline \multirow{2}{*}{$\begin{array}{l}\text { Performance } \\
\text { Expectancy }\end{array}$} & Perceived Usefuness/ Response & I & l & I & I & I \\
\hline & Efficacy & & & & & \\
\hline Effort Expectancy & Perceive Ease of use & I & l & I & I & I \\
\hline Social Influence & Subjective Norm & I & I & & I & I \\
\hline \multirow[t]{2}{*}{ Facilitating Condition } & $\begin{array}{l}\text { Self Efficacy (Perceived Internal } \\
\text { Behavioral Control) }\end{array}$ & & l & & I & I \\
\hline & $\begin{array}{l}\text { Response Cost (Perceived External } \\
\text { Behavioral Control) }\end{array}$ & & & & & \\
\hline Hedonic Motivation & Fun Pleasure & & & & & I \\
\hline \multirow[t]{4}{*}{ Perceive Risk } & Social & & & & & \\
\hline & Performance & & & & & \\
\hline & Security & & & & & \\
\hline & Time & & & & & \\
\hline Motivating Factor & Trigger factor & & & & & \\
\hline Impeding Factor & Personal Desire & & & & & \\
\hline
\end{tabular}

TRA, TPB, TAM and UTAUT has been acknowledge as the prominent technology acceptance models and generally utilized by a large portion of inquiries. TRA has its own constraint where dispositions and standards can cause perplexity. Current demeanor may allude to the standards and the other way around. TRA likewise did not clarify 
positively on the conduct and there are need of outer factors, for example, propensity and natural impediment to help the discoveries. In the interim, TPB are relied upon to determine the confinement of TRA, yet the social standards factors appear not bring any critical to behavioral aim. TAM indicates general determinants of individual less emphasize and clarifying the conduct or behavior. In the interim UTAUT which was gotten from various acknowledgment models has top to bottom comprehension and disclose either user aim on the technology usage.

In order to compare the models above, the constructs and moderator in explaining user behavior are being summarized in the Table 3 which concludes four models with their respective explained variance.

Explained variance is very important to predict behavior of the user towards technology acceptance (Venkatesh, Morris, Davis, \& Davis, 2003). Table show TRA has most minimal difference run which is 0.36 contrasted with UTAUT 0.69 . While TAM2 and TPB fluctuates between 0.52 to 0.53 and 0.36 to 0.47 individually to various mediator appended to it. UTAUT has strong informative and better comprehension of behavioral expectation. It has been clarifies that UTAUT has solid ability and a superior model use for breaking down behavior of the user from emerging number of empirical evidence and researches.

Table 3. Comparison of explained variance in technology acceptance theories

\begin{tabular}{llll}
\hline Theory/Model & Construct(IV) & Moderators & $\begin{array}{l}\text { Explain } \\
\text { Variance (R2) }\end{array}$ \\
\hline $\begin{array}{l}\text { Theory of Reasoned Action } \\
\text { (TRA) }\end{array}$ & $\begin{array}{l}\text { 1.Attitude towards behaviour } \\
\text { 2.Subjective Norms }\end{array}$ & $\begin{array}{l}\text { 1.Experience } \\
\text { 2.Voluntariness }\end{array}$ & 0.36 \\
\hline $\begin{array}{l}\text { Theory of Planned Behaviour } \\
\text { (TPB) }\end{array}$ & $\begin{array}{l}\text { 1.Attitude towards behaviour } \\
\text { 2.Subjective Norm }\end{array}$ & $\begin{array}{l}\text { 1.Gender } \\
\text { 2.Experience }\end{array}$ & 0.46 \\
& 3.Perceive Behavioral Control & & \\
\hline $\begin{array}{l}\text { Technology Acceptance Model } \\
\text { (TAM)-including gender }\end{array}$ & 1.Perceive Usefulness & 1.Experience & 0.52 \\
& 2.Perceive ease of use & 2.Voluntariness & \\
\hline $\begin{array}{l}\text { Unified Theory of Acceptance } \\
\text { and Use of Technology }\end{array}$ & 3.Subjective Norm & \\
(UTAUT) 2.Effort Expectancy & 2.Gender & 0.69 \\
& 3.Social Influence & 3.Experience & \\
& 4.Facilitatting Condition & 4.Voluntariness & \\
\hline
\end{tabular}

\section{Methodology}

The first step on doing this research is to identify broad area of interest and formulating research problem through preliminary review on the literature. In order to develop a structure and focus for the research study, literature review is used as it involves the process summary or evaluation of critical analysis of related literature on a particular area. Published source which includes journals, articles, and other respective sources that are directly related to the area of interest provides the information by which a study's validity is judged. Research structure was adopted from of past study and the focus was locked by presenting research questions, hypotheses and objectives.

Next, is to conceptualize research design which is descriptive research and use survey to investigate the correlational and relationship between variables that have been identified. After the methodology has been identified, research model and instrument for data collection are being developed. Furthermore, pilot studies have been conducted to examine reliability of the questions to 10 respondents. After the final revision of the instrument, data collection was carried out and collected to measure relationship of the variables of the hypotheses testing before being documented in meaningful way according to the results that have been gathered.

\subsection{Research Structure}

This study is using quantitative method to study technology acceptance of EPV with population of the study are from accounting student of Universiti Teknologi Mara (UiTM). At first, the survey is deployed to only student with accounting background by using google form and respondents demographic are being recorded and they need to 
provide their email for the study. The questionnaires consist of questions from UTAUT2 construct and used likert-scale which has been marked 1 as "Strongly Disagree" and 5 as "Strongly Agree" only one answer is required for each question. Data are then being collected and analyzed by using statistical computer programs known as IBM SPSS. Results are then will be interpreted to know technology acceptance of EPV application by accounting students.

\subsection{Research Model}

Research model is used as a guide for displaying the factors included and illustration of how the factors collide with each other. Unified Theory of Acceptance and Use of Technology (UTAUT) is chosen to be use in this study as it comprises factors and connection towards behavioral aim. Regardless of considerable use of UTAUT2 as a method for anticipating the practices, research inquire to keeps on looking at extra factors that may be more reasonable in specific conditions. As for newly introduces system which is EPV application, price value and habit construct are being excluded for this study which will be detailed out in the Figure 1.

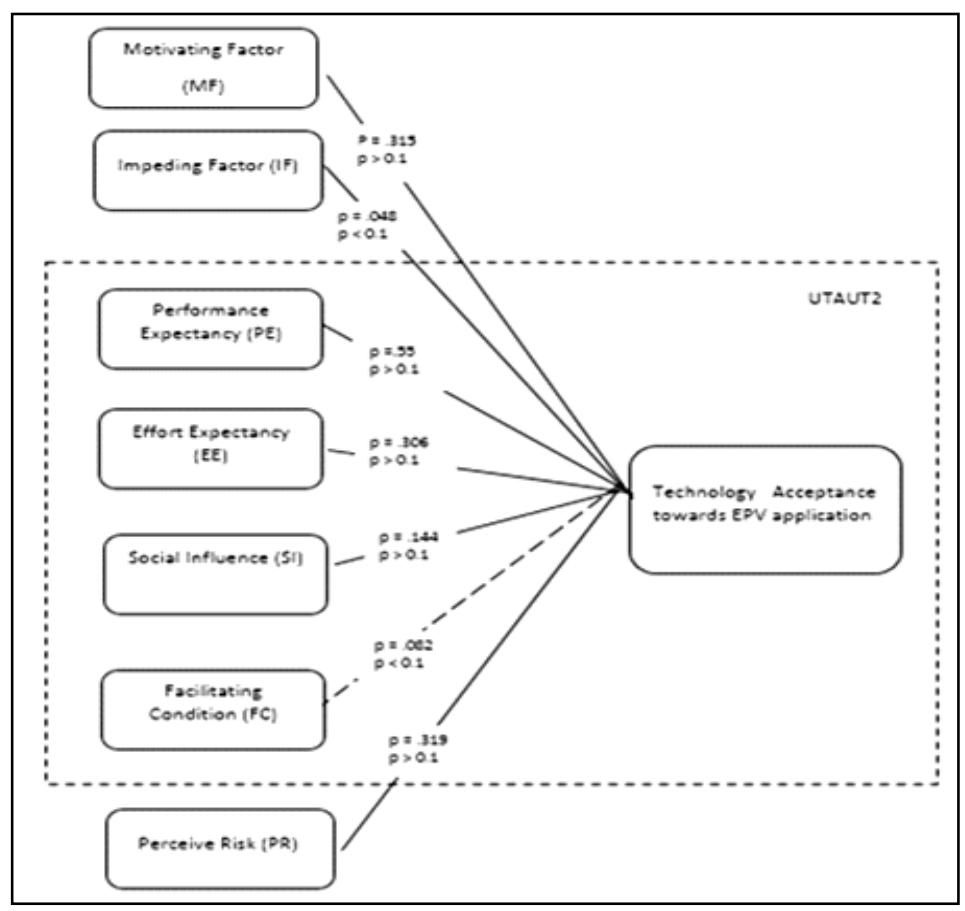

Figure 1. Modified unified theory of acceptance

\section{Empirical Results and Discussion}

Hypothesis testing is used to evaluate two mutually exclusive statements about a population to determine which statement is best supported by the sample data. For each independent variable, two hypotheses are being constructed and only one is accepted based on the result from the test. In order to visualize clearly the hypothesis testing, relationship

has been described in the modified model namely technology acceptance towards EPV. The result from hypothesis testing are listed and summarized in Table 4.

Table 4. Hypothesis testing result

\begin{tabular}{llll}
\hline Hypothesis & Relationship & Results & Supported \\
\hline H1 & There is a significant factor between motivating factor and & $\mathrm{p}=.315$ & $\mathrm{Y}$ \\
& technology acceptance & $\mathrm{p}>0.1$ & \\
\hline
\end{tabular}




\begin{tabular}{|c|c|c|c|}
\hline $\mathrm{H} 2$ & $\begin{array}{l}\text { There is a significant factor between impeding factor and } \\
\text { technology acceptance }\end{array}$ & $\begin{array}{l}\mathrm{p}=.048 \\
\mathrm{p}<0.1\end{array}$ & $\mathrm{Y}$ \\
\hline H3 & $\begin{array}{l}\text { There is a significant factor between performance expectancy } \\
\text { and technology acceptance }\end{array}$ & $\begin{array}{l}\mathrm{p}=.559 \\
\mathrm{p}>0.1\end{array}$ & $\mathrm{Y}$ \\
\hline $\mathrm{H} 4$ & $\begin{array}{l}\text { There is a significant factor between effort expectancy and } \\
\text { technology acceptance }\end{array}$ & $\begin{array}{l}\mathrm{p}=.306 \\
\mathrm{p}>0.1\end{array}$ & $\mathrm{Y}$ \\
\hline H5 & $\begin{array}{l}\text { There is a significant factor between social influence and } \\
\text { technology acceptance }\end{array}$ & $\begin{array}{l}p=.144 \\
p>0.1\end{array}$ & $\mathrm{Y}$ \\
\hline H6 & $\begin{array}{l}\text { There is a significant factor between facilitating condition and } \\
\text { technology acceptance }\end{array}$ & $\begin{array}{l}\mathrm{p}=.082 \\
\mathrm{p}>0.1\end{array}$ & $\mathrm{Y}$ \\
\hline $\mathrm{H} 7$ & $\begin{array}{l}\text { There is no significant factor between hedonic motivation and } \\
\text { technology acceptance }\end{array}$ & $\begin{array}{l}\mathrm{p}=-.415 \\
\mathrm{p}<0.1\end{array}$ & $\mathrm{~N}$ \\
\hline H8 & $\begin{array}{l}\text { There is a significant factor between perceive risk and } \\
\text { technology acceptance }\end{array}$ & $\begin{array}{l}p=.391 \\
p>0.1\end{array}$ & $\mathrm{Y}$ \\
\hline
\end{tabular}

The proposed model for analyzing technology acceptance of EPV application consist of 7 significant construct tested using Pearson Correlation test as illustrated in Figure 3.

From the result of correlation matrix as illustrates on the modified UTAUT2 model, there are significant correlation between the variables which means the proposed model are accepted by the user.

The modified model construct is then will be test using Multiple Linear Regression to get the explained variance (R2). Explained variance are statistical techniques usually applied to unravel the relationship between variables in numerical form based on the understanding that all errors are in the dependent variable, the independent variable having been measured without errors or in simpler terms, how much explained variance will influence the dependent variables. This is important because, by knowing R2 of EPV application, the acceptance of the modified model will be verified and acknowledge if the value is more than previous research model (TRA, TPB, TAM and UTAUT) that investigate the model's explained variance as explained in literature review. 


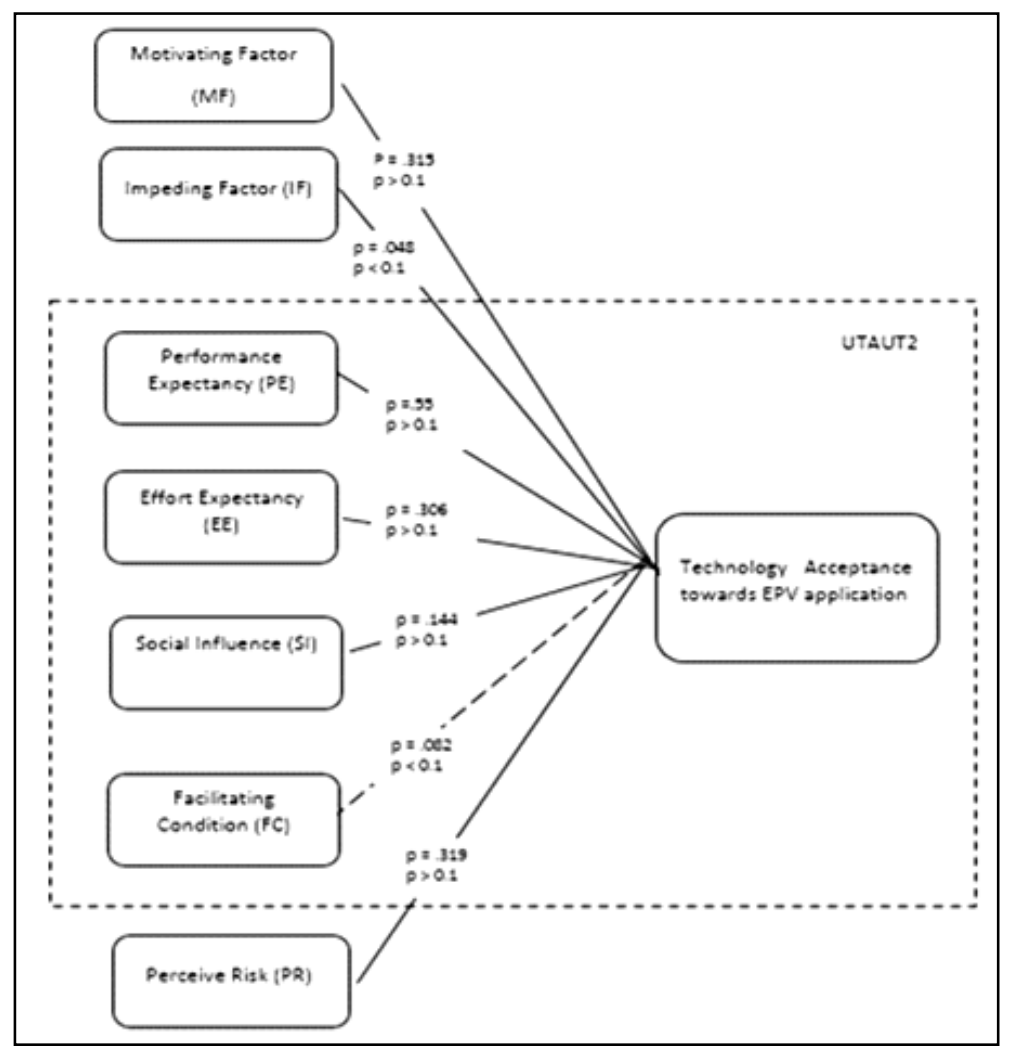

Figure 3. Modified UTAUT2 with correlation value

Furthermore, regression is used to find each contribution from independent variable of the propose model towards dependent variable in which for this study, to find the technology acceptance of EPV application. In order to put all question from same construct into a new independent variable which hold the average of the variables, we use "compute variable" function in SPSS. One function of multi linear correlation is it may estimate which independent variables influence the most towards dependent variables (aLi \& Haseeb, 2019).

The result after running regression shows that 7 construct of modified model explains $78.8 \%$ of technology acceptance towards EPV application which means a better improvement in determining technology acceptance rather than using another 4-research model. TRA, TPB, TAM and UTAUT research model which have been studied previously by Venkatesh et al, 2003; Kripanont, 2007; Dulle, 2010 contributes in explaining technology acceptance by 36\%, 46\%, 52\% and 69\% respectively (Samaradiwakara \& Gunawardena, 2014; Lee \& Chou 2018).

Based on the findings, 7 out of 8 independent variables have been justified to be the factor of technology acceptance of EPV application (Refer Table 5). Thus, to analyze the technology acceptance of the user, a modified UTAUT2 model are being constructed namely technology acceptance towards EPV application. Motivating Factor (MF), Impeding Factor (IF), Performance Expectation (PE), Effort Expectation (EE), Social Influence(SI), Facilitating Condition(FC) and Perceive Risk(PR) are the positive factor that affects technology acceptance as a result from Pearson Correlation test. Pearson Correlation are used to study the validity of instrument being created as it would be used in developing a model and correlation value is being compared to identify which factor most likely influence technology acceptance of EPV application.

Table 5. Regression analysis result of TAEPV

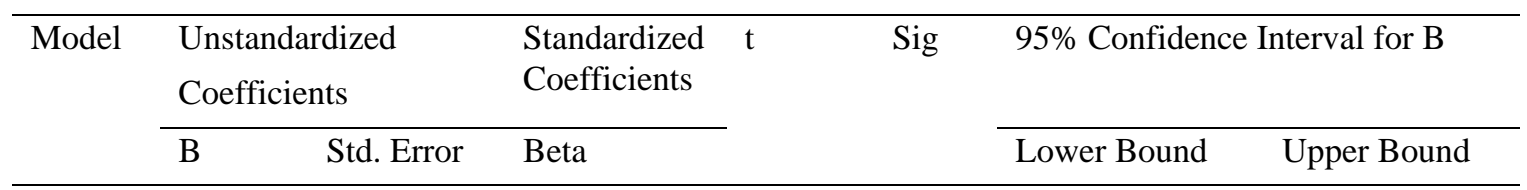




\begin{tabular}{llllllll}
\hline const & -49.81 & 19.81 & & -2.514 & .019 & -90.6 & -8.99 \\
\hline MF & -.71 & .12 & -2.49 & -5.923 & .000 & -.962 & -.465 \\
\hline IF & -.135 & .03 & .78 & 3.918 & .001 & .064 & .206 \\
\hline PE & 1.05 & .45 & 2.43 & 2.354 & 0.27 & .132 & 1.983 \\
\hline EE & .14 & .31 & .16 & .472 & .641 & -.492 & .784 \\
\hline SI & .88 & .26 & 3.34 & 3.440 & .002 & .356 & 1.419 \\
\hline FC & 1.35 & .47 & 2.55 & 2.910 & .007 & .396 & 2.311 \\
\hline PR & .31 & .05 & 1.60 & 6.642 & .000 & .215 & .409 \\
\hline
\end{tabular}

Performance expectancy have been identified to be strong positive influence towards technology acceptance. PE is the degree to which users gain benefits in using a technology while carrying out activities (Sun \& Wang, 2013; Massoro \& Othman 2018). Kit, Ni, Badri and Yee (2014) mentioned that usefulness is the degree a person belief using system would enhance performance are the important factor in determining user behavior.

Meanwhile, hedonic motivation shows no significant relationship towards technology acceptance with $\mathrm{p}=-0.415$ which means it is not suitable to be a factor to determine technology acceptance of EPV application. Hedonic Motivation (HM) have been identified to be medium negative influence towards technology acceptance. HM is the fun or pleasure derived from using a technology (Kit, Ni, Badri \& Yee, 2014). Most respondent feels that a professional system does not have to be fun and exciting does making the direction is negative. Besides, they agree that EPV should operates professionally to indicates individual's ethical performances. The result of the study aligns with Lewis et al. (2013) that found using partial least squares that HM do not positively influence the intention to use classroom technology, based on a survey conducted on instructors in Southeastern University in the United States of America. Furthermore, Nine Usability Heuristic which is simple and natural dialogue; speak the user's language; minimize user memory load; be consistent; provide feedback; provide clearly marked exits; provide shortcuts; good error messages; prevent errors rather than the application/system should be fun and exciting thus making hedonic motivation being excluded to study technology acceptance of EPV application (Kljucnikov, Belas, Kozubikova \& Pasekova, 2016; Mahmoud, 2016).

\section{Conclusions}

This study has brought advantages in identifying factors influencing technology of newly introduces application which is Ethical Personality Value (EPV) judgement system. Using EPV, board of director may access and view performance of his/her employee as a whole in real time which also cater for employee's view about their opinion on senior management level. We recommend dashboard should be able to present the data from each assessment of the user in meaningful and useful as board of director may synthesizes the data to make further plan.

As for next recommendation is regarding methodology of developing instrument for survey questionnaires which is using modified UTAUT2. Therefore, it is hoped that future study will investigate the correlation of technology acceptance of EPV application for a new population which is for financial auditors in the organization to study their acceptance and use behavior.

As for the conclusion, growing economy in our country doesn't mean we are free from unethical conduct and negative behavior among netizen especially professional who works in the professional setting. Amanuddin et al (2015) states that Malaysia is one of many countries around the world that are influenced with negative perception regarding corruption and fraud incidents.

Auditors' awareness on ethical issues during working in the workplace is low because they pay less attention towards the issues both for individual and on the hierarchical level (Aprilliani, Anggaraini, \& Anwar, 2014). Plus, there are expanding number of unethical issues among auditing organizations despite of their association with worldwide organization which have disappointed many people, for example, Enron Energy and World Com, which makes credibility of the auditor being questioned and has taken a solid beating.

Moreover, auditors often face problems in their practice of expert judgment and not being cater thoroughly even with the implementation code of conduct. Also, the credibility of the auditor is rather questionable when they have personal association with their customers, as this may impact their mental state of mind and supposition. In this manner, it is vital for an auditor to keep honest and observing their own particular ethical behavior and make good 
and correct professional judgement.

Ethical behaviors not only protect the individuals but also the auditing profession as a whole to secure public confidence while using the service. To achieve good level of auditor performance and improve the confident of public toward the services provided by the organization, a professional measurement to test auditor's ethical performance are on demands. The acceptance of newly develop Ethical Personality Value (EPV) application which comes with risk associated with it need to be studied so that proper corrective action can be taken to solve the issues.

Therefore, it is hoped that the Ethical Personality Value (EPV) application would be able to assist individuals in making decision involving issues on ethical problem. The quality of decision making of audit professionals can be enhanced as EPV can be adopt as self-monitoring tools which align with government imitative to fight corruption and ethical issues comprehensively using technology such as big data and IoT.

\section{Acknowledgment}

The authors gratefully acknowledge the financial grant Accounting Research Institute (ARI), Universiti Teknologi MARA, Malaysia and Faculty of Computer and Mathematical Sciences for all supports and resources.

\section{References}

Ahmed, U., Zin, M. L. M., \& Majid, A. H. A. (2016). Impact of Intention and Technology Awareness on Transport Industry's E-service: Evidence from an Emerging Economy. IJIDB, 7(3), 13-18. https://doi.org/10.13106/ijidb.2016.vol7.no3.13.

Ajzen, I. (2011). The theory of planned behaviour: reactions and reflections. Psychology and Health, 26(9), 1113-1127. https://doi.org/10.1080/08870446.2011.613995

Ali, A., \& Haseeb, M. (2019). Radio frequency identification (RFID) technology as a strategic tool towards higher performance of supply chain operations in textile and apparel industry of Malaysia. Uncertain Supply Chain Management, 7(2), 215-226. https://doi.org/10.5267/j.uscm.2018.10.004

Amanuddin, et al. (2015). The Perception and Intention of the Malaysian Enforcement Agencies' Employees on the Whistleblower Protection Act. Journal of Education and Social Science, 53(9), 266-276. https://doi.org/10.1017/CBO9781107415324.004

Aprilliani, D., Anggaraini, R., \& Anwar, C. (2014). The Effect of Organization Ethical Culture and Ethical Climate on Ethical Decision Making of Auditor with Self Efficacy as Moderating. Review of Integrative Business and Economic, 4(1), 226-244.

Bakhtiari, M., \& Azimifar, M. (2013). Impact of professional ethics on financial reporting quality. Advances in Environmental Biology, 7(10), 2862-2866.

Berger, A.N., Klapper, L.F., Martinez-Peria, M.S., \& Zaidi. R. (2008). Bank ownership and banking Relationships. Journal of Financial Intermediation, 17, 37-62. https://doi.org/10.1016/j.jfi.2006.11.001

Davis, F. D. (1989). Perceived usefulness, perceived ease of use, and user acceptance of information technology. MIS Quarterly, 319-340. https://doi.org/10.2307/249008

Detragiache, E., Tressel, T., \& Gupta, P. (2006). Foreign banks in poor countries: Theory and evidence. IMF Working Paper No. 18. International Monetary Fund, Washington DC. https://doi.org/10.5089/9781451862782.001

EPQ Forsyth, D. R. (1980). A taxonomy of ethical ideologies. Journal of Personality and Social Psychology, 39(1), 175. https://doi.org/10.1037/0022-3514.39.1.175

EUROSAI Task Force on Audit \& Ethics (2014). Auditing Ethics in the Public Sector, 1-81. Retrieved from https://www.eurosai.org/handle404?exporturi=/export/sites/eurosai/.content/documents/working-groups/audit-et hics/RelDoc/TFAE_paper-Auditing-Ethics-in-Public-Sector.pdf

Fernandés, O. (2014). Psychometric Assessment and Its Impact on Human Resource Practices. Retrieved from http://www.cutn.sk/Library/proceedings/mch_2015/editovane_prispevky/7Fernandes_Psychometric.pdf

Fiserova, T., Teply, P., \& Tripe, D. (2015). The performance of foreign-owned banks in the host country economics. Prague Economic Papers, 24(5), 1-24. https://doi.org/10.18267/j.pep.527

Fishbein, M., \& Ajzen, I. (1977). Belief, attitude, intention and behaviour: An introduction to theory and research. Philosophy and Rhetoric, 10(2), 130-132. 
Hunt, S. D., Wood, V. R., \& Chonko, L. B. (1989). Corporate ethical values and organizational commitment in marketing. Journal of Marketing, 53(3), 79-90. https://doi.org/10.1177/002224298905300309

Hussin, S. A. H. S., \& Iskandar, T. M. (2015). Re-validation of professional skepticism traits. Procedia Economics and Finance, 28, 68-75. https://doi.org/10.1016/S2212-5671(15)01083-7

Jermsittiparsert, K. (2016). Culture of 'Elephant front legs-hind legs': A debate on the actuality of sexual politics in Thai society. The Social Sciences, 11(1), 20-28.

Johari, R. J., Mohd Sanusi, Z., \& Ismail, A.H. (2012). Exploratory Factor Analysis of the Ethical Orientation Scale. Asian Journal of Accounting \& Governance, (3), 1-11. https://doi.org/10.17576/ajag-2012-3-6511

Johari, R. J., Mohd. Sanusi, Z., \& Vincent, K. C. (2017). Effects of Auditors' Ethical Orientation and Self-Interest Independence Threat on The Mediating Role of Moral Intensity and Ethical Decision-Making Process. International Journal of Auditing, 2l(1), 38-58. https://doi.org/10.1111/ijau.12080

Kit, A. K. L., Ni, A. H., Badri, E. N. F. B. M., \& Yee, T. K. (2014). UTAUT2 influencing the behavioural intention to adopt mobile applications. Universiti Tunku Abdul Rahman.

Kljucnikov A., Belas, J., Kozubikova, L., \& Pasekova P. (2016).The Entrepreneurial Perception of SME Business Environment Quality in the Czech Republic. Journal of Competitiveness, 8(1), 66-78. https://doi.org/10.7441/joc.2016.01.05

Kung, F.-H., \& Huang, C. L. (2013). Auditors moral philosophies and ethical beliefs. Management Decision, 51(3), 479-500. https://doi.org/10.1108/00251741311309616

Lee, C. H., \& Chou, P. I. (2018). Corporate cash holdings and product market competition: The effects of stock-based executive compensation. Asian Economic and Financial Review, 8(9), 1140-1157. https://doi.org/10.18488/journal.aefr.2018.89.1140.1157

Lewis, C. C., Fretwell, C. E., Ryan, J., \& Parham, J. B. (2013). Faculty use of established and emerging technologies in higher education: A unified theory of acceptance and use of technology perspective. International Journal of Higher Education, 2(2), 22-34. https://doi.org/10.5430/ijhe.v2n2p22

Lin, T. Y. (2018). Two-Stage Performance Evaluation of Domestic and Foreign Banks in Taiwan. Asian Journal of Economic Modelling, 6(2), 191-202. https://doi.org/10.18488/journal.8.2018.62.191.202

Liu, C. C., \& Kao, J. S. (2018). A Study of the Impact of Business Strategy on Customers Tourism Behaviors, Motivation, and Satisfaction-A Case Study of Hotels at Kenting, Taiwan. International Journal of Asian Social Science, 8(8), 486-500. https://doi.org/10.18488/journal.1.2018.88.486.500

Liu, H. H., \& Wang, T. K. (2018). The Survival of the Sunset Textile Industry Involving Bilateral Free-Trade Agreements: Empirical Evidences of Taiwan. Asian Journal of Economic Modelling, 6(2), 157-171. https://doi.org/10.18488/journal.8.2018.62.157.171

Liu, M., Zhu, J., Bian, Y., \& Chen, L. (2018). Comprehensive Credit Risk Management of Policy Export Credit Insurance Institutions. Journal of Accounting, Business and Finance Research, 4(2), 66-73. https://doi.org/10.20448/2002.42.66.73

Loukil, K. (2017). Technological Innovation in Central and Eastern Europe: What's the Contribution of Innovation Policy?. The Economics and Finance Letters, 4(1), 1-8. https://doi.org/10.18488/journal.29.2017.41.1.8

Mahmoud, O. (2016). Managerial Judgement Versus Financial Techniques in Strategic Investment Decisions: An Empirical Study on the Syrian Coastal Region Firms. https://doi.org/10.18488/journal.62/2016.3.3/62.3.31.43

Massoro, Z. Z., \& Othman, R. (2018). Antecedents of Citation Impact and Intention to Publish on Open Access Journals: A Case of Agricultural Research Institutes Tanzania. International Journal of Emerging Trends in Social Sciences, 4(2), 86-96. https://doi.org/10.20448/2001.42.86.96

Mobaraki, M. (2012). Introducing Some Psychometric Tests for Researching on Cognitive Processes of the Translators I Translation Students. Theory and Practice in Language Studies, 2(5), 1069-1074. https://doi.org/10.4304/tpls.2.5.1069-1074

Mohamed Alteer, A., Bin Yahya, S., \& Harashid Haron, M. (2013). Auditors' Personal Values and Ethical Judgement At Different Levels of Ethical Climate: a Conceptual Link. Journal of Asian Scientific Research, 3(8), 862-875. https://doi.org/10.5923/c.economics.201301.20

Mohd Iskandar, T., Nelly Sari, R., Mohd-Sanusi, Z., \& Anugerah, R. (2012). Enhancing auditors' performance: The 
importance of motivational factors and the mediation effect of effort. Managerial Auditing Journal, 27(5), 462-476. https://doi.org/10.1108/02686901211227959

Mohd-Sanusi, Z., \& Mohd-Iskandar, T. (2006). Audit judgment performance: assessing the effect of performance incentives, effort and task complexity. Managerial Auditing Journal, 22(1), 34-52. https://doi.org/10.1108/02686900710715639

Morris, J. T. (2009, February). The impact of authentic leadership and ethical organizational culture on auditor behavior. Journal of Behavioral Studies in Business, 7, 1-33.

Mustapha, M., \& Lai, S. J. (2017). Information Technology in Audit Processes: An Empirical Evidence from Malaysian Audit Firms. International Review of Management and Marketing, 7(2), 53-59.

Samaradiwakara, G. D. M. N., \& Gunawardena, C. G. (2014). Comparison of existing technology acceptance theories and models to suggest a well improved theory/model. International Technical Sciences Journal, 1(1), 21-36.

Shamsuddin, A., Manijegar, D. B., Kirupanangtan, K., Rahman, S., \& Selvanathan, S. (2014). Factors that determine the effectiveness of internal audit functions in the malaysian public sectors. International Journal of Business, Economics and Law, 5(1), 9-17. http://ijbel.com/wpcontent/uploads/2014/12/ACC-13-Factors-that-Determine-the-Effectiveness-of-Internal-Aud it-Functions-in-The-Malaysia-Public-Sectors.pdf

Sun, Y., \& Wang, N. (2013). Understanding the Acceptance of Mobile Health Services: A Comparison and Integration of Alternative Models. Journal of Electronic Commerce Research, 14(2), 183-200.

Venkatesh, V., Morris, M. G., Davis, G. B., \& Davis, F. D. (2003). User Acceptance of Information Technology: Toward a Unified View. MIS Quarterly, 27(3). https://doi.org/10.2307/30036540

Venkatesh, V., Thong, J. Y., \& Xu, X. (2012). Consumer acceptance and use of information technology: extending the unified theory of acceptance and use of technology. MIS quarterly, 36(1), 157-178. https://doi.org/10.2307/41410412

Yaghoubi, N. (2011). Behavioral approach to policy making of the internet banking industry: The evaluation of factors influenced on the customers ' adoption of internet banking services. African Journal of Business Management, 5(16), 6785-6792. 